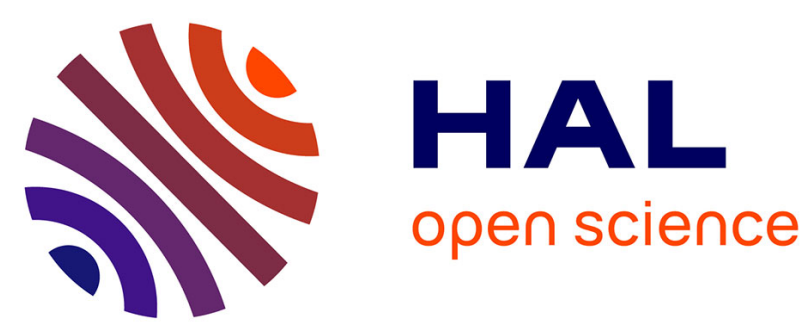

\title{
LARGE PLAYERS IN THE NANOGAME: DEDICATED NANOTECH SUBSIDIARIES OR DISTRIBUTED NANOTECH CAPABILITIES?
}

Vincent Mangematin, Khalid Errabi, Caroline Gauthier

\section{- To cite this version:}

Vincent Mangematin, Khalid Errabi, Caroline Gauthier. LARGE PLAYERS IN THE NANOGAME: DEDICATED NANOTECH SUBSIDIARIES OR DISTRIBUTED NANOTECH CAPABILITIES?. Journal of Technology Transfer, 2011, 36 (6), pp.640-664. 10.1007/s10961-011-9209-8 . hal-00526726

\section{HAL Id: hal-00526726 \\ http://hal.grenoble-em.com/hal-00526726}

Submitted on 15 Oct 2010

HAL is a multi-disciplinary open access archive for the deposit and dissemination of scientific research documents, whether they are published or not. The documents may come from teaching and research institutions in France or abroad, or from public or private research centers.
L'archive ouverte pluridisciplinaire HAL, est destinée au dépôt et à la diffusion de documents scientifiques de niveau recherche, publiés ou non, émanant des établissements d'enseignement et de recherche français ou étrangers, des laboratoires publics ou privés. 


\title{
LARGE PLAYERS IN THE NANOGAME: DEDICATED NANOTECH SUBSIDIARIES OR DISTRIBUTED
} NANOTECH CAPABILITIES?

\author{
Vincent Mangematin, Khalid Errabi and Caroline Gauthier, \\ Grenoble Ecole de Management (GEM) \\ 12 rue Pierre Sémard, 38000 Grenoble, France \\ Phone: + 33476706058 \\ Contact e-mail: vincent.mangematin@grenoble-em.com \\ Website : $\underline{w w w . n a n o e c o n o m i c s . e u}$
}

\begin{abstract}
Nanotechnologies are reshaping the boundaries between industries, combining two aspects of innovation - both enhancing competences based on cumulative knowledge and experience and destroying competences by forcing the renewal of the firm's knowledge base. To analyze how worldwide R\&D leaders adapt to this new technology, we conduct an econometric analysis of about 3,000 subsidiaries of the largest $R \& D$ spenders. We find that large groups are creating medium size subsidiary companies to explore nanotechnologies. Knowledge circulates mostly amongst subsidiaries within the same group and scientific clusters do not affect their involvement in nanotechnologies. Nanotechnologies remain marginal within these subsidiaries' knowledge bases and are distributed within corporate groups, stimulating recombination between nanotechnology and other technologies.
\end{abstract}

Keywords: incumbent, inflexibility, hybridization, nanotechnology, pre-adaptation

Acknowledgements: we acknowledge the financial support of ANR (ANR-07-NANO-02601) and of the FP7 European project FRIDA (FP7-SSH-2007-1). The authors would like to thank the participants of the MCOI seminar (www.grenoble-innovation.eu). We are grateful to Jon Morgan for his paper editing. Usual caveats apply. 


\title{
Large Players in the Nanogame: Dedicated Nanotech Subsidiaries or Distributed Nanotech Capabilities?
}

\begin{abstract}
Nanotechnologies are reshaping the boundaries between industries, combining two aspects of innovation - both enhancing competences based on cumulative knowledge and experience and destroying competences by forcing the renewal of the firm's knowledge base. To analyze how worldwide R\&D leaders adapt to this new technology, we conduct an econometric analysis of about 3,000 subsidiaries of the largest R\&D spenders. We find that large groups are creating medium size subsidiary companies to explore nanotechnologies. Knowledge circulates mostly amongst subsidiaries within the same group and scientific clusters do not affect their involvement in nanotechnologies. Nanotechnologies remain marginal within these subsidiaries' knowledge bases and are distributed within corporate groups, stimulating recombination between nanotechnology and other technologies.
\end{abstract}

Keywords : incumbent, inflexibility, hybridization, nanotechnology, pre-adaptation 
Nanotechnologies are seen as having the potential to revolutionize many scientific fields and many industries, in particular by fostering convergence between previously distinct technology-driven sectors (Rocco et al., 2007). These expectations are not solely about the creation of scientific fields, but also concern the transformation of existing markets and the involvement of firms in developing nanotechnology-based products and processes for such markets. In contrast to biotechnologies - which are largely organized around drug development processes - the changes associated with nanotechnologies mainly concern their introduction into existing products or processes (Bozeman, et al. 2007, Rothaermel et al., 2007). Large firms which already have products in the markets may have a competitive advantage in engaging in nanotechnologies: this paper analyses the ways in which worldwide R\&D leaders are involved in nanotechnologies.

Defined as the ability to work at the scale of a nanometer (i.e., one-billionth of a meter), nanotechnologies impact existing industries by enabling new combinations, such as the merging of microelectronics and biotechnology in nanobiotechnologies, and downscale of existing fields such as microelectronics in nanoelectronics and chemistry in nanochemistry. Nanotechnologies combine two aspects of innovation - enhancing competences based on cumulative knowledge and experience, and destroying them by forcing the renewal of the firm's knowledge base (Linton et al., 2008). Rothaermel and Hill (2005b) show that a competence destroying technological discontinuity will decrease incumbent firm performance if the complementary assets of the new technology are generic, but increase it if they are specialized. In such a context - where technological discontinuities are both competence destroying and competence enhancing (Loveridge et al., 2008) - how do large firms invest in nanotechnologies? How intense is their involvement? How do their knowledge bases evolve? We address these questions by focusing on how the world's biggest R\&D performers are investing in nanotechnologies. The firms under analysis are subsidiary companies of groups in the 2008 list of the 1,400 biggest R\&D performers worldwide (source: DTI, UK). 2,986 subsidiaries (of 768 of these groups) are active in nanotechnologies patented nanotechnologies between 1998 and 2006. We concentrate on the forms of their involvement in nanotechnology, characterizing their knowledge bases by analyzing their patents, and measuring the breadth of their R\&D activities based on the US Patent Office Classification, their degree of specialization in nanotechnologies and thus how their involvement in nanotechnologies has developed other time.

Across the whole period, nanotechnologies have remained marginal in the patent portfolios of large groups, which are already highly diversified. But these large R\&D performers create 
medium size companies to explore nanotechnologies and prepare for their evolution towards them. These subsidiaries have been set up recently, but are not dedicated to nanotechnologies: rather they combine nanotechnologies with other recent technologies. Nanotechnology innovations have been included in existing products or processes, within existing business models, but - as in the cases of ICT and (to a lesser extent) biotech - new business models may also emerge that are based on applications that include nanotechnologies.

The following section discusses what forms of investment in new technologies large firms employ, emphasizing pre-adaptation and the constitution of multi-dimensional absorptive capacity. The third section presents the empirical data and methods, and the fourth examines the results, showing the determinants of investment in nanotechnologies. The last section discusses the theoretical implications of the role of large R\&D performers in emerging technologies.

\section{FIRM INVOLVEMENT IN NANOTECHNOLOGIES}

Innovation management scholars generally describe the pattern of development alternating incremental and radical innovations that spur the emergence of new technologies (Abernathy et al., 1978; Anderson et al., 1990; Tushman et al., 1986). During rapid phases of change, new entrants outperform incumbents who, according to Henderson (1993), tend to under-invest in radical innovation because they fall into competency traps (Levitt and March, 1988) and face core rigidities (Leonard-Barton, 1992). However, large incumbent firms are often responsible for considerable numbers of innovations, and Rosembloom (2000), Rothaermel and Hill (2003) and Cattani (2006) have explored ways in which they initiate radical innovations. Incumbent firms can adapt and survive, and even regain high market performance levels. Under what circumstances do incumbents outperform start-ups in introducing radial innovations?

Hill and Rothaermel (2003) emphasize that many empirical analyses have described how incumbents succeed in benefiting from radical innovations. Radical technological innovation "involves methods and materials that are novel to incumbents. [They] are derived from either an entirely different knowledge base or from the recombination of parts of the incumbents' established knowledge base with a new stream of knowledge". The degree of novelty is assessed by comparison with the existing knowledge base: incremental innovations build on technologies that already exist in a firm's knowledge base, while more radical innovations are those deriving from technologies which it has not yet mastered. The standard model suggests that radical innovations which create new market opportunities damage and destroy the demand for existing products. When such innovations succeed in the market place, they alter 
established demand and supply conditions - demand for existing products declines as consumers switch purchasing to products based on newer technologies. The discontinuities triggered by radical technological innovations see incumbents challenged by the rise to dominance of new entrants. Hill and Rothaermel examine the reasons behind incumbent underperformance in terms of introducing radical innovations. Inflexibility is seen as the first source: Reinganum (1983) emphasizes that incumbents have incentives to produce incremental innovations which serve to consolidate their existing knowledge base, increase barriers to entry and protect their existing stream of products. But they have disincentives to produce radical innovations that, if successful, risk eroding their market power, and which can be introduced to new entrants, who can adopt them to penetrate incumbents' markets. Hannan and Freeman (1989) argue that large incumbent firms value predictability and reliability, and so refrain from radically changing their knowledge bases. Nelson and Winter (1982) consider the routines by which large firms are performing day to day activities, and note how the cumulative science and technology paths of incumbents who have been investing in specific trajectories for a long time reinforce their inflexibility. Their records, knowledge and routines are historical and timeembedded, and they benefit from increasing returns to their accumulated knowledge. A second source of inertia is based on the importance of power and politics within established firms. Radical innovation involves organizational change which leads to a redistribution of power, which can tend to 'break the truce' and trigger political upheaval within organizations (Cyert et al., 1963; Pfeffer, 1992). Finally, incumbent inflexibility can be explained with strategic lens: such firms are embedded within value networks of suppliers, consumers, complementary product suppliers and even investors, bankers and stakeholders, which have contributed to their past success. When radical innovation threatens to trigger radical changes, such networks can prove highly inflexible, usually because of the substantial (and irreversible) strategic commitments involved, which match established employee competencies. The standard model thus concludes that incumbents are stuck in their specific trajectories, which are highly inflexible, and this leads to the decline of established firms in the face of the kind of market discontinuities typically triggered by radical innovations.

However, some incumbents survive and prosper - and even pioneer radical innovations of their own - and can go on to dominate the post-discontinuity phase. While the average performance of incumbents declines after the introduction of radical innovations, there is considerable variation in the rate and depth of this decline, even across firms within the same industry. Hill and Rothaermel (2003) explored different reasons to explain why some incumbent outperform the industry average performance, and suggest loosely coupled basic and applied research, the 
use of real options perspective to evaluate investment in technology, an organizational structure which allows and legitimizes autonomous action, a history of turbulence within the industry, etc. as features of 'survivors' strategies. When they are facing technologies that promise to simultaneously enhance and destroy their competences, incumbents can benefit from their competitive advantages by recombining parts of their knowledge base with new knowledge streams (Freeman et al., 1997). Incumbents develop technological pre-adaptation capabilities i.e. knowledge that they have accumulated over time in related technical fields but without anticipating its subsequent use (Cattani, 2006). Focusing on Corning's fiber optics strategy, he highlights the dynamics of technological speciation which sees an incumbent redeploying part of its existing technological knowledge base into a new domain. Preadaptation capabilities are investments in absorptive capacity, increasing the firm's ability to acquire knowledge in the future. Technological pre-adaptation creates a bundle of capabilities awaiting recognition, where the firm can be seen as developing options it can take up as and when new information emerges about possible applications for its knowledge stock. To take up such options, there needs to be a overlap between the technological pre-adaptation and the evolutionary state of the market.

When technologies emerge to challenge existing ones, uncertainty increases and the possibilities of foresight are reduced. In the highly turbulent markets that ensue, pre-adaptation capabilities allow incumbent firms to adapt more quickly to produce radical innovation. Diversifying their knowledge base, they increase their absorptive capacity in different fields, building their ability to identify promising scientific and technological fields and finally hybridizing their knowledge base with new knowledge streams.

Nanotechnology is a new and much hyped technology: public authorities are investing in them, stimulating the formation of clusters, subsidizing researches and encouraging firms which invest in nanotechnologies. Firms from different industries are turning microelectronics into nanoelectronics, biotechnology into nanobiotechnology etc., generating high uncertainty and turbulence. Focusing on this emerging potential for radical innovations based on converging technologies, this paper analyses how large firms invest in nanotechnologies. Which are the modalities? and how do nanotechnology capabilities develop?

Given that nanotechnologies have emerged only very recently, it is difficult to assess the performance of firms involved as Nesta (2008) did for the world's largest manufacturing corporations. We therefore focus on the forms of involvement in nanotechnologies by large firms to better understand their pre-adaptation strategies and emerging patterns of industrial organization. Do large firms create dedicated subsidiary companies? Or are nanotechnologies 
integrated in firms amongst other technologies?

We contrast two forms of involvement in nanotechnologies: on the one side, dedicated nanofirms have been set up during the last decade, and are mostly science based, as was the case in biotechnologies. They are patenting as well as publishing, and invest in nanotechnologies as a specific technology, starting with the emergence of nanotechnologies. They are usually located in clusters, where tacit knowledge can be circulated easily. On the other hand, firms which develop a diversified knowledge base that includes nanotechnologies tend to hybridize them with their existing technologies. Nanotechnologies are spread within large groups, they are distributed amongst subsidiary companies which are weakly involved in that new technology (i.e. not dedicated to nanotechnologies). Pre-adaptation capabilities plays an important role in developing capabilities for nanotechnologies. These subsidiaries are not new - they are substantial business with established track records and existing knowledge bases, and are developing nanotechnologies as an additional technology and a diversification, mainly via patenting with less publishing activity.

To characterize subsidiary companies' involvement in nanotechnologies, we define the notion of nanoinvolvement. as the proportion of nanopatents to the total number of patents in the subsidiary company's knowledge base. This variable thus measures the extent to which nanotechnologies are 'entering' the firm knowledge base and to which they affect its patent portfolio structure. Low nano-involvement means nanotechnology remains marginal to a firm's knowledge base. Nanotechnology is distributed amongst the different subsidiaries. Low nanoinvolvement means nanotechnology remains marginal to a firm's knowledge base, and the knowledge is distributed amongst the group's different subsidiaries. High nanoinvolvement of subsidiary companies describes firms which are more 'nanodedicated', meaning that the expertise is concentrated within one company of the group and less widely distributed within the group.

Based on existing research in biotechnology (Nesta, 2008), we first consider the diversity of the knowledge base as a key variable to characterize the concentration or distribution of nanotechnologies within a subsidiary. If diversity is high, nanotechnology represents a small proportion of the subsidiary knowledge base, but at the same time, increases the chances that it will take nanotechnologies on board in the future. Low diversity (i.e., high concentration) of the knowledge base means that nanotechnology is concentrated within one subsidiary and poorly distributed within the group.

To explore the paths of subsidiaries' involvement in nanotechnologies, we identify different variables that might influence firms' degree of involvement in nanotechnology: internal 
characteristics as internal diversity of the knowledge base and investment in $R \& D$; the size of the group and whether they are located within a nano-specialized cluster.

Size matters as it influences the concentration on nanotechnology. So diversity has to be moderated by the size of the knowledge base.

Proposition 1: The lower the diversity, moderated by the

size of the subsidiary knowledge base, the higher the

involvement of the subsidiary.

The immediate environment of a firm plays an important in the pre-adaptation strategy. When technologies are emerging, proximity is key to the efficient exchange of tacit knowledge, as is usually the case with geographic proximity within clusters. When the subsidiary company is located in a nano-specialized cluster (Bozeman et al., 2007; Mangematin et al., 2010), the geographic proximity with other actors involved in nanotechnology may increase its involvement in nanoresearch, so we can also propose that:

\section{Proposition 2: Firms situated within nanoclusters have}

greater nanoinvolvement than those outside nanoclusters

High concentration on nanotechnologies within a single subsidiary may indicate a poorly distributed technology which remains focused. But successful pre-adaptation requires the development of absorptive capacity and distributed nanotechnologies to prepare hybridization: so both the involvement of the group in $R \& D$ and the repartition of the involvement in nanotechnology within subsidiary play a role. Boschma (Boschma, 2005) shows that proximity takes different forms. While geographic proximity has been the most explored mode of circulation of tacit knowledge, organizational proximity (i.e. being in the same firm or in the same group) allows tacit knowledge to be more easily accessed and thus to circulate better. Analyses of the breadth of knowledge base at the firm level are based on its size and diversity. But internal diversity is not the only way to increase a firm's capacity to absorb knowledge: the firms under review all belong to groups, and, based on how knowledge circulation is organized within the group (Birkinshaw, 2002), the breadth of the knowledge base may be considered at the group level instead of just the subsidiary level. We can assume that the larger the group's R\&D investment, the higher will be the group's diversity and the more likely it is that subsidiaries will be specialized. Thus:

Proposition 3: The higher the $R \& D$ expenditures of the group, the higher the involvement of subsidiaries 
To explore how large groups engage with nanotechnologies, we focus on the worldwide largest $R \& D$ spenders - groups which were selected because they already have research records in different technological fields - and we focus on those of their subsidiaries that have at least one nanotechnology patent.

\section{DATA AND METHODOLOGY}

Nanotechnology can be defined as the manipulation of molecular sized materials to create new products and processes that derive novel features from their nanoscale properties. Nanotechnology promises to have the potential to revolutionalize many industry sectors, in particular by fostering convergence between sectors driven by previously distinct technology. Only 20 years have elapsed since IBM invented its tunneling and atomic force microscopy instruments, so nanotechnology is still in its early stages - but is changing very quickly. Scientific production in nanotechnologies has been booming, with increasing numbers of firms involved, while publications in the field multiplied three-fold between 1998 and 2006.

\section{Data collection}

To explore the three hypotheses, we built a database of firms involved in nanotechnologies. We adopted a three stages process: first, identifying the largest R\&D groups worldwide; second, discovering which of their subsidiary companies were involved in nanotechnologies; third, examining the patent portfolios of those subsidiaries to measure their involvement in nanotechnologies.

First step: The UK DTI's 2008 R\&D Scoreboard is an international league table of the companies investing most in $\mathrm{R} \& \mathrm{D}$, and gives details of the top 1400 global companies (the 'G1400') ranked by their R\&D investment. The database identifies the ultimate parent companies, but does not rank subsidiaries separately and therefore had to be matched against a database of the firms involved in nanotechnologies.

Second step: To build this database of the firms involved in nanotechnologies, we first identified actors researching in nanotechnologies. We use a validated search strategy based on keywords (Mogoutov et al., 2007) to extract publications from the ISI/Web of Science from 1998-2008, and patents from the PATSTAT EPO patent database, which collects data from 73 offices worldwide, where we identified 617,000 applications in nanotechnologies from among over 65,000,000 patents. From these sources we identified 10,499 companies which published or patented in nanotechnologies. 6,731 firms only patented, 2,768 firms both published and patented and we excluded 1,000 Firms which only published. We end up with a total of 9,499 
companies active in nanotechnologies.

Third step: Matching the two databases from the first and second steps, we found 2,986 companies involved in nanotechnology that were subsidiary companies of DTI G1400 groups. (About 55\% - 768 out of the 1,400 - of the DTI G1400 firms were involved in nanotechnologies.)

Tables 1 and 2 describe the main characteristics of our population of 2,986 companies which were subsidiaries of the world's 1,400 largest R\&D spenders in 2008 and which were involved in nanotechnologies (which we label 'nanofirms').

Table 1: Characteristics of firms involved in Nanotechnologies (by geographical area)

\begin{tabular}{l|r|r|r|r}
\hline $\begin{array}{l}\text { Geographical } \\
\text { Area(EN) }\end{array}$ & $\begin{array}{c}\text { \% of Total } \\
\text { Nano Firms }\end{array}$ & $\begin{array}{c}\text { \% of Total DTI } \\
\text { 2008 Nano } \\
\text { Subsidiaries }\end{array}$ & $\begin{array}{c}\text { \% of Total DTI } \\
\text { 2008 } \\
\text { Nanogroup }\end{array}$ & $\begin{array}{c}\text { Share of Nano } \\
\text { DTI 2008 (\% of } \\
\text { G1400) }\end{array}$ \\
\hline US \& Canada & 36.79 & 34.9 & 37.15 & 31.29 \\
\hline EU27 & 35.22 & 33.22 & 28.07 & 23.64 \\
\hline ASIA & 18.75 & 25.22 & 24.26 & 20.43 \\
\hline OTHERS & 9.24 & 6.66 & 10.52 & 8.86 \\
\hline Total & 100.00 & 100.00 & 100.00 & - \\
\hline Number & 9,499 & 2,986 & 786 & - \\
\hline
\end{tabular}

We can observe that more than $90 \%$ of the world's nanofirms are located in Asia, Europe and US/Canada. While US and Canada have the largest numbers, the proportion of large firms there is lower than in Asia. Altogether, about 31.4\% of the firms involved in nanotechnology R\&D are subsidiaries of the G1400 groups, which is a very high proportion, especially considering that some $55 \%$ of largest $\mathrm{R} \& \mathrm{D}$ groups are involved in nanotechnology, whatever the original industry of the firm.

Table 2 describes the main industries of these nanofirms, and compares the proportion of G1400 subsidiaries with the total number of firms in those groups. This 'nanoinvolvement' is highest in the health care equipment and service industry (where it focuses on instrumentation) and also very high in the Pharmaceutical, metals and Oil\&Gas industries. 
Table 2: DTI Firms By Industry

\begin{tabular}{|l|r|r|r|r|r|r|r|}
\hline $\begin{array}{l}\text { Industry-DTI } \\
\text { Company- }\end{array}$ & $\begin{array}{c}\text { No. of } \\
\text { Subsidiaries }\end{array}$ & $\begin{array}{c}\text { No. of Nabsidiaries } \\
\text { Subsidiaries }\end{array}$ & $\begin{array}{c}\text { \% of Total } \\
\text { Share (\%) }\end{array}$ & $\begin{array}{c}\text { Nobso. of } \\
\text { Subsiaries }\end{array}$ & $\begin{array}{r}\text { No. of Nano } \\
\text { Applications }\end{array}$ & $\begin{array}{c}\text { Nano } \\
\text { Applications }\end{array}$ & $\begin{array}{c}\text { Patenting } \\
\text { Involvement } \\
(\%)\end{array}$ \\
\hline $\begin{array}{l}\text { Techn hardware \& } \\
\text { equipment }\end{array}$ & 11,685 & 653 & 5.59 & 21.87 & $2,160,810$ & 42,541 & 1.97 \\
\hline Chemicals & 9,047 & 333 & 3.68 & 11.15 & $1,444,508$ & 29,328 & 2.03 \\
\hline Pharma \& bio & 8,334 & 364 & 4.37 & 12.19 & 644,231 & 18,711 & 2.9 \\
\hline Automobiles & 7,223 & 194 & 2.69 & 6.5 & 772,067 & 7,925 & 1.03 \\
\hline $\begin{array}{l}\text { Electronic \& } \\
\text { electrical equipt }\end{array}$ & 6,592 & 297 & 4.51 & 9.95 & $1,556,147$ & 29,049 & 1.87 \\
\hline $\begin{array}{l}\text { Industrial } \\
\text { engineering }\end{array}$ & 4,145 & 126 & 3.04 & 4.22 & 226,804 & 4,855 & 2.14 \\
\hline $\begin{array}{l}\text { Health care equipt \& } \\
\text { services }\end{array}$ & 3,544 & 106 & 2.99 & 3.55 & 99,727 & 6,826 & 6.84 \\
\hline Oil \& gas & 2,944 & 99 & 3.36 & 3.32 & 105,520 & 3,845 & 3.64 \\
\hline Industrial metals & 2,526 & 74 & 2.93 & 2.48 & 191,211 & 5,483 & 2.87 \\
\hline Others & 22,509 & 647 & 2.87 & 21.71 & $2,863,541$ & 46,571 & 1.62 \\
\hline Total & 77,383 & 2,986 & 3.87 & 100 & $10,340,588$ & 201,281 & 1.95 \\
\hline
\end{tabular}

The fact that nanoactivities are dispersed among (and inducing changes in) different industries underlines the 'general purpose' character of nanotechnologies and the way they are impacting different industries with different research trajectories. Nano patenting activity remains low in all industries; around $2 \%$ of the knowledge base (against about $4 \%$ of subsidiaries being involved in nanoactivities). Altogether, the 2,986 subsidiaries on our database filled about a third $(201,281 / 617,000)$ of the patent applications in nanotechnologies over our study period (1998-2006). Few groups are central in research and innovation in nanotechnologies.

\section{Data analysis and estimation strategy}

Our estimation strategy was based on using OLS regressions to estimate the determinants of the nanoinvolvement which measures the extent to which nanotechnologies enter firm knowledge bases - i.e. the proportion of nanotech patent applications to total applications over the whole period (see appendix 2). The exogenous variables that we explain are defined as follows (see Appendix 1 for details):

- Variables describing the local environment take two different dimensions: the geographic area involved (EU27, Asia, US-Canada, other) and whether the firm performs its activity within a nanotech cluster (Clust), which we define as geographic agglomerations of nanotech research capacities (Mangematin et al., 2010).

- The second group of variables concerns the industry dimension, which are defined from the subset of 1,115 DTI subsidiaries that are also listed in ORBIS database (one of the main sources of worldwide economic and financial firm data). We define the industry in 
which firms' activities are based by their NACE codes (Chemical Ind., Electronic Ind., S\&T Serv Ind., Machinery Ind.).

- The third group controls for firm size as defined in ORBIS (SmallF/MediumF/LargeF) based on turnover and number of employees for the same subset of ORBIS listed firms (see appendix 1).

- The fourth group describes the knowledge base of each subsidiary firm. First, knowledge base size is calculated by its total numbers of applications and of nano-applications ( $K B$ size (Sub) and NanoKB size (Sub-applic)). Second, knowledge base diversity is estimated by the technological diversity of the firm's patents, which measures the breadth of its nano $R \& D$ activities to ascertain if they are concentrated in a small number or spread over a larger number of fields. Field definitions are based on the International Classification for Patents. Diversity is measured at two levels: IPC1 (the more aggregated level) measures the degree of involvement of the firm in different technological fields, and IPC4 (more detailed) which represents the diversity within the technological specialization of the knowledge base. Thus IPCI represents the diversity of the firm's technologies as a whole, at the more general level, and is labeled 'diversity at large', while IPC4 ('concentrated diversity') describes diversity within proximate technological classes. Borrowing a tool used in industrial organization to measure market concentration, we take 1 minus the Herfindhal index as our measure of diversity (Patel et al., 1995), which theoretically yields values between 0 and 1, with larger index values corresponding to greater diversity. To avoid co-linearity, we define Mean_IPC1 as the average number of classes at IPC1 level.

- The fifth group describes the characteristics of the group: its NACE code (Group_industry), the percentage of its subsidiaries involved in nanotechnologies (Group_nanofirmsshare), and the group $\mathrm{R} \& \mathrm{D}$ expenditures $(R \& D$ and employees in 2007).

\section{RESULTS}

To understand the involvement of large groups in nanotechnologies, we analyze the involvement of their subsidiary companies in nanotechnologies by running an OLS regression which analyzes the determinants of the intensity of that involvement in three different steps:

We calculate a first model, (appendix 3, Table 4) with all the variables; We then run a model to optimize the adjusted $\mathrm{R}^{2}$ (appendix 3 table 5); Finally, we run a stepwise selection model (10\%) (table 3 ) with the significant variables. 
Table 3 : Model with Stepwise selection at 10\% (model quality)

\begin{tabular}{llll}
\hline Root MSE & $\mathbf{0 . 1 1 9 1 1}$ & R-Square & $\mathbf{0 . 7 3 6 3}$ \\
\hline Dependent Mean & 0.13628 & Adj R-Sq & 0.7343 \\
Coeff Var & 87.40047 & & \\
\hline
\end{tabular}

Table 3 : Model with Stepwise selection at 10\% (model estimations)

\begin{tabular}{|c|c|c|c|c|c|c|}
\hline $\begin{array}{l}\text { Parameter Estimates } \\
\text { Variable }\end{array}$ & Label & DF & $\begin{array}{l}\text { Parameter } \\
\text { Estimate }\end{array}$ & $\begin{array}{l}\text { Standard } \\
\text { Error }\end{array}$ & $\mathrm{t}$ Value & $\operatorname{Pr}>|t|$ \\
\hline Intercept & Intercept & 1 & 0.81785 & 0.03785 & 21.61 & $<.0001$ \\
\hline First_Patent_Nano & $\begin{array}{l}\text { First Patent is Nano Patent } \\
\text { Dummy }\end{array}$ & 1 & 0.13901 & 0.01254 & 11.09 & $<.0001$ \\
\hline Medium_firm & Medium Company Dummy & 1 & 0.04952 & 0.01312 & 3.77 & 0.0002 \\
\hline LgKB size (Sub)_SQ & $\begin{array}{l}\text { Square Log Number of } \\
\text { applications }\end{array}$ & 1 & -0.00399 & 0.00022311 & -17.87 & $<.0001$ \\
\hline $\begin{array}{l}\text { LgNanoKB } \\
\text { applic)_SQ }\end{array}$ & $\begin{array}{l}\text { Square Log Number of nano } \\
\text { applications }\end{array}$ & 1 & 0.00767 & 0.00047776 & 16.06 & $<.0001$ \\
\hline DIV_IPC4 & Diversity Index (1-HHI) (IPC4) & 1 & -0.72154 & 0.02943 & -24.51 & $<.0001$ \\
\hline Mean_IPC1 & Mean Number(IPC1) & 1 & 0.03107 & 0.01489 & 2.09 & 0.0372 \\
\hline GROUP_NanoInvolvement & $\begin{array}{l}\text { Group's Nano Patenting } \\
\text { Involvement }\end{array}$ & 1 & 0.31979 & 0.03590 & 8.91 & $<.0001$ \\
\hline GROUP_NanoFirmsShare & Group's Nano Firms Share & 1 & 0.00008885 & 0.00004526 & 1.96 & 0.0499 \\
\hline
\end{tabular}

Table 3 describes the firm involvement in nanotechnologies. Overall, the stepwise model provides us with a adjusted $\mathrm{R}^{2}$ of $73.4 \%$, which can be considered very good. At a general level, the involvement of the subsidiary in nanotechnology increases when the firm is medium size (operating revenue at least $\$ 1.4 \mathrm{~m}$ or more than 15 employees), and decreases with the size of the knowledge base. The diversity of the knowledge base at the more aggregated level (IPC1) has a positive impact on the involvement in nanotechnology (mean number of IPC), but at the more detailed level (IPC4) the diversity of the knowledge base has a negative impact, revealing dedicated nanotechnology patents. Technological diversity has a positive impact when it is taken at the more aggregated level and a negative impact at the more detailed level. In general terms, the more involved the group is in nanotechnology, the more dedicated to nanotechnology its subsidiaries will be, revealing the presence of intra organization technological spillovers. Similarly, when nanotechnologies are more widely distributed within the group, subsidiaries are more dedicated to nanotechnologies, combining their local technology with nanotechnology. Surprisingly, those subsidiaries that are set up to develop nanotechnologies (i.e, where their first patent is in a nanotechnology - which applies to about $32 \%$ of the subsidiaries) go on to combine nano with a technology that is radically different.

We end up with a mixed picture of small and medium size subsidiaries with patents which merge widely differentiated classes of technologies. To understand the logics of involvement in nanotechnologies, we explore each of our propositions.

Proposition 1 posits a specialization in nanotechnologies for the subsidiary, as had been the 
case in biotechnologies. The OLS regression with all the variables and the covariance table (Appendices 2 and 3) show a balanced picture: the first patent in nano is significant and positive, but that subsidiaries also seem to patent simultaneously in technological domains very far from nanotechnologies. Diversity within the closest technological classes around nanotechnologies seems to have a negative impact: it seems that subsidiaries that are developing nanotechnologies also then hybridize them with another (distant) technology.

Proposition 2 is not supported by the empirical analysis. Geographic spillovers through proximity within clusters do not play a key role in increasing the involvement of firms in nanoresearch: none of the geographic areas plays a significant role. It seems that large groups are implementing similar strategies whatever the area and whatever the industry. The preadaptation strategies of large groups seem to be quite limited. Groups develop nanotechnologies by setting up or acquiring small and medium companies which then patent first in nanotechnology.

Proposition 3 which is stating that higher R\&D investment of the group leads to higher involvement of subsidiaries is not directly supported, but the general involvement of the group in nanotechnologies and the distribution of nanotechnology within subsidiaries play a positive role in the subsidiary nanoinvolvement. Organizational proximity plays a role: it seems that intragroup spillovers affect subsidiaries' involvement in nanotechnologies, so that the more widely nanocompetencies are distributed within the group, the more subsidiaries can specialize. The level of group R\&D expenditures (appendix 4) also plays a positive role on the nanoinvolvement of its subsidiaries.

Surprisingly, the involvement of the subsidiary in basic science - which leads to publication plays no role (appendix 4). Nanotechnologies seem not to be as science-based as biotechnologies were. The absence of impact of scientific clusters may be interpreted in the same way - the nanoinvolvement of a subsidiary is not influenced by its level of scientific activity.

During this emerging phase, worldwide R\&D leaders are only investing in nanotechnologies to a limited extent, by creating small and medium subsidiary firms to explore the nanofield. These firms, which are not purely science based, are patenting in nanotechnologies but only publishing to a marginal extent. Nanotechnologies appear to be General Purpose Technologies, which have been defined as "new method[s] of producing and inventing that is important enough to have a protracted aggregate impact" (Jovanovic et al. 2005, p 1182). They are combined with other technologies which are in different classes for purposes of further 
exploitation. The finding that none of the industries or of the technological fields are significant reinforces the sense of general purpose patterns that can be used in different markets (Gambardella et al., 2010; Grid, 2009). Bresnahan and Trajenberg (Bresnahan et al., 1995) and Jovanovic and Rousseau (Jovanovic et al., 2005) explain how such technologies contribute to growth, while Gambardella and McGahan (2010) emphasize the impact of a General Purpose Technology on industry structure, showing how it can extract value from different markets. Large groups are preparing for the emergence of nanotechnologies through their subsidiaries, and this pre-adaptation does not take the form of investments in close technological fields, but rather involves combining nanotechnologies with technologically far distant fields. Investments in nanotechnology are generic, so they can be combined with new technologies with the existing knowledge base. World-class R\&D spenders, which have large and diverse knowledge bases, are investing in nanotechnology via subsidiary companies, and setting up new ventures to perform $R \& D$ in nanotechnologies. Nanotechnologies are originating a new pattern of development, with a marginal investment at the group level, distributed capabilities amongst subsidiaries and circulation within the group rather than within scientific clusters.

\section{DISCUSSIONS}

Nanotechnology presents specific patterns of development, being mostly a business of large firms. Investments by the world's largest $R \& D$ spenders remain marginal to their main efforts, and are mostly channeled firms via a few of their medium-sized subsidiaries. The study of large groups involved in nanotechnologies displays a landscape which is different from that of biotechnologies. The following discussion is organized around three arguments: the specificities of nanotechnologies; predaptation in a technology based field, and implications for research.

\section{Specificities of nanotechnologies}

In addition to the many small players who are driving scientific developments in the field, nanotechnologies are also the domain of large players: 768 of the world 1400 largest groups have between them filled about 1/3 of the nanotechnologies patents applications via 2,986 of their subsidiary companies. Nanotechnologies are closer to the market than biotechnologies were at a similarly early stage of their development. The promise of nanotechnologies is based on their ability to redefine existing industries, through new combinations, merging microelectronics with biotechnology, with chemistry, etc. Large groups involvement in nanotechnologies means that knowledge is circulated amongst them and their subsidiaries 
which is creating global absorptive capacities.

While this number still only represents a marginal proportion (4\%) of these groups' total set of subsidiaries - and nanotechnology still represents only a limited element in their knowledge bases - between them, they have filled one third of the total nanotechnology patent applications. So we can say that nanotechnology is developing within large firms, and even if it remains marginal in their global knowledge bases, there are highly concentrated developments within a small number of companies.

\section{Pre-adaptation, absorptive capacity and hybridization}

In his Corning case study, Cattani (2006) describes pre-adaptation mechanisms as part of a firm's technological knowledge base that is accumulated without anticipation of its subsequent uses, and underlines the decision process behind such investment. From an econometric point of view, Cohen and Levinthal (1990) analyze absorptive capacity as a by-product of R\&D investment, and since their seminal paper, the notion of absorptive capacity has been further qualified. Mangematin and Nesta (1999) explored the different vehicles by which knowledge is absorbed, while Knott (2008) has examined asymmetric absorptive, and Cattani has explored how the structure of the knowledge base affects absorption. Inspired by Freeman and Soete (1997), this paper analyses firms' strategies designed to increase the scope of their knowledge base by pre-adaptation. It describes technological pre-adaptation, where groups are developing internal capacities to combine their existing knowledge with breakthrough innovations emerging from their ability to work at the nanoscale. Nanotechnologies seem to have the characteristics of general purpose technologies, which can be used in different markets, thus enhancing these large groups' ability to combine them with other technologies. Knowledge circulation is organized within the groups and nanotechnologies are distributed to different subsidiaries. One explanation is that nanotechnologies can either be dedicated to specific applications, or can be mobilized as generic technologies to improve processes or the characteristics of existing products. Surprisingly, even though nanotechnologies are emerging from scientific research, they are mostly applied in technological modes: there are no significant roles for scientific clusters, and little publication involved.

Nanotechnologies appear as a new way to disseminate and create value from new technologies. Compared to biotechnologies - which have been developed by small firms and marketed through alliances between start-ups and large firms close to the market - nanotechnologies are developed and marketed by the same firms which then embed them into existing products and devices. While pre-adaptation has seemed marginal in biotechnologies (as exploration has been 
performed by small firms) it becomes central when new technologies have to be hybridized with existing knowledge.

\section{CONCLUSIONS}

The results show an interesting landscape where large firms are developing pre-adaptation to be able to hybridize their knowledge base with these newly emerging technologies. This preadaptation is conducted by the creation of new ventures which patent first in nanotechnologies, which are then distributed within the organization. Thus the nano-landscape differs from that of biotechnology. In biotechnology, the innovation process has been divided between small firms which invest in $R \& D$ and large firms closer to the markets, which ally with high tech start-up to access new technologies. In that framework, successful technology transfer between small and large firms is vital, and access to market appears as a bottleneck for start-ups. Preadaptation of large firms is not necessary in such a situation - it is achieved though their networks and alliances with small firms. In nanotechnologies, in contrast, large firms are investing in pre-adaptation in order to speed up the development of new technologies when markets emerge. The managerial implications are twofold: regarding industrial organization, technology transfer is less important than in biotechnologies, as cooperation between large firms and universities has usually been routinized for a long time. In addition, it seems that collaborations amongst organizations (university, public labs, small and large firms) should be organized around shared technological platforms, such as the nanocenters that have been developed at Minatec in France or Albany in the USA.

Regarding research avenues, pre-adaptation and enhancing the scope of the knowledge are becoming critical factors for nurturing innovation based on hybridization between existing knowledge bases and new technologies. Surprisingly, it seems that hybridization is mainly based on the mobilization of internal knowledge: rather than organizing inter-organization collaboration, this emphasizes the need to better understand how knowledge circulates amongst distant units. In such situations, where pre-adaptation is critical, public policies should aim to stimulate research around nanotechnologies, but avoid over focusing on them specifically: as general purpose technologies, nanotechnologies need to be merged with existing knowledge. Basic research capacity and experience remain keys, to increase absorptive capacity, so public policies need support basic research and collaboration with universities and research organizations so as to parallel firms in their general purpose technology investments. Researches on the organization and distribution of knowledge within large groups are important to better understand the respective roles of organization and geographic proximities. 


\section{REFERENCES}

47

Abernathy WJ, Utterback J. 1978. Patterns of Industrial Innovation. Technology Review 80: 41-

Anderson P, Tushman ML. 1990. Technological Discontinuities and Dominant Designs : A Cyclical Models of Technological Change. Administrative Science Quarterly 35(4): 604-633

Birkinshaw J. 2002. Managing Internal R\&D Networks in Global Firms - What Sort of Knowledge Is Involved? Long Range Planning 35(3): 245-267

Boschma RA. 2005. Proximity and Innovation. A Critical Assessment. Regional Studies 39(1): $61-74$

Bozeman B, Laredo P, Mangematin V. 2007. Understanding the Emergence and Deployment of "Nano" S\&T. Research Policy 36(6): 807-812

Bresnahan TF, Trajtenberg M. 1995. General Purpose Technologies "Engines of Growth?" Journal of Econometrics, Annals of Econometrics 65(1): 83-108

Cattani G. 2006. Technological Pre-Adaptation, Speciation, and Emergence of New Technologies: How Corning Invented and Developed Fiber Optics. Industrial and Corporate Change 15(2): 285-318

Cohen WM, Levinthal DA. 1990. Absorptive Capacity, a New Perspective of Learning and Innovation. Administrative Science Quarterly 35: 128-152

Cyert M, March JG. 1963. The Firm as an Adaptative Institution, A Behavioral Theory of the Firm: 289-304

Freeman C, Soete L. 1997. The Economics of Industrial Innovation. MIT Press: Cambridge, MA

Gambardella A, McGahan A. 2010. Business-Model Innovation: General Purpose Technologies and Their Implications for Industry Structure. Long Range Planning 43(2)

Grid T. 2009. Striving for a Large Market: Evidence from a General Purpose Technology in Action. Industrial and Corporate Change 18(1): 107-138

Hannan MT, Freeman J. 1989. Organizational Ecology. Harvard University Press: Cambridge, Massachusetts London, England

Henderson RM. 1993. Underinvestment and Incompetence as Responses to Radical Innovation: Evidence from the Photolithographic Alignment Equipment Industry. RAND Journal of Economics 24(2): $248-270$

Hill CWL, Rothaermel FT. 2003. The Performance of Incumbent Firms in the Face of Radical Technological Innovation. Academy of Management Review 28(2): 257

Jovanovic B, Rousseau PL. 2005. General Purpose Technology. In P Aghion, SN Durlauf (Eds.), Handbook of Economic Growth. Elsevier

Knott AM. 2008. R\&D/Returns Causality: Absorptive Capacity or Organizational Iq. Management Science 54(12): 2054-2067

Linton JD, Walsh ST. 2008. Acceleration and Extension of Opportunity Recognition for Nanotechnologies and Other Emerging Technologies. Beschleunigung und Erweiterung der Wahrnehmung unternehmerischer Gelegenheiten für Nanotechnologie und andere neue Technologien. 26(1): 83-99

Loveridge D, Dewick P, Randles S. 2008. Converging Technologies at the Nanoscale: The 
Making of a New World? Technology Analysis \& Strategic Management 20(1): 29-43

Mangematin V, Nesta L. 1999. What Kind of Knowledge Can a Firm Absorb? International Journal of Technology Management 37(3-4): 149-172

Mangematin V, Rieu C. 2010. The Determinants of Science-Based Cluster Growth: The Case of Nanotechnology. RMT Working paper series

Mogoutov A, Kahane B. 2007. Data Search Strategy for Science and Technology Emergence: A Scalable and Evolutionary Query for Nanotechnology Tracking. Research Policy 36(6)

Nelson RR, Winter SG. 1982. An Evolutionary Theory of Economic Change. Havard University Press.

Nesta L. 2008. Knowledge and Productivity in the World's Largest Manufacturing Corporations. Journal of Economic Behavior \& Organization 67(3-4): 886-902

Patel P, Pavitt K. 1995. Patterns of Technological Activity : Their Measurement and Interpretation. In P Stoneman (Ed.), Handbook of the Economics of Innovation and Technilogical Change: 14-51. Blackwell: Oxford (UK) and Cambridge (USA) $29-50$

Pfeffer J. 1992. Understanding Power in Organizations. California Management Review(winter):

Reinganum JF. 1983. Uncertainty Innovation and the Persistance of Monopoly. American Economic Review 73: 741-748

Rocco M, Bainbridge WS (Eds.). 2007. Nanotechnology: Societal Implications. Springer: Dorsdrescht

Rosenbloom RS. 2000. Leadership Capabilities and Technological Change: The Transformation of Ncr in the Electronic Era. Strategic Management Journal 21: 1083-1103

Rothaermel FT, Hill CWL. 2005a. Technological Discontinuities and Complementary Assets: A Longitudinal Study of Industry and firm Performance. Organization Science 16(1): 52-70.

Rothaermel FT, Hill CWL. 2005b. Technological Discontinuities and Complementary Assets: A Longitudinal Study of Industry and Firm Performance. Organization Science 16(1): 52-70

Rothaermel FT, Thursby M. 2007. The Nanotech Versus the Biotech Revolution: Sources of Productivity in Incumbent Firm Research. Research Policy 36(6): 832-849

Tushman M, Anderson P. 1986. Technological Discontinuities and Organizational Environments. Administrative Science Quarterly 31: 439-465

Zucker LG, Darby MR, Furner J, Liu RC, Ma H. 2007. Minerva Unbound: Knowledge Stocks, Knowledge Flows and New Knowledge Production. Research Policy 36(6): 850-863\%U 


\section{Appendix 1}

Table. Detailed list of variables

\begin{tabular}{|c|c|c|}
\hline \# & Variable & Label \\
\hline \multicolumn{3}{|c|}{ Endogenous variables } \\
\hline 1 & Nanoinvolvement & Nano Patenting Intensity \\
\hline 2 & Nanoinvolvement25_bis & Nano Patenting Intensity(2002-2005) (\# of Total 2002-2005) \\
\hline \multicolumn{3}{|c|}{ Control variables } \\
\hline 21 & DumASIA & Geographic Dummy ASIA (control Other) \\
\hline 22 & DumEU27 & Geographic Dummy EU27 (control Other) \\
\hline 23 & DumUSCanada & Geographic Dummy US \& Canada (control Other) \\
\hline 24 & Chemical Ind. & Industry dummy Chemical industry \\
\hline 25 & Electronic Ind. & Industry dummy Computer \& Electronic Product industry \\
\hline 26 & S\&T Serv Ind. & Industry dummy Professional, Scientific \& Technical Services \\
\hline 27 & Machinery Ind. & Industry dummy Machinery industry \\
\hline 28 & Other Ind. & (NAICS07_3D) OTHERS Industries Dummy \\
\hline 29 & NAICS07_4D & NAICS 2007(4D) \\
\hline 30 & NAICS07_3D & NAICS 2007(3D) \\
\hline 31 & NAICS07_2D & NAICS 2007(2D) \\
\hline \multicolumn{3}{|c|}{ Knowledge base of the subsidiary } \\
\hline 4 & KB size (Sub) & Total Number of patent Applications \\
\hline 11 & LgKB size (Sub) & Log of total Number of patent applications \\
\hline 3 & NanoKB size (Sub) & Total Number of Scientific Publications in nanotechnology \\
\hline 5 & NanoKB size (Sub- applic) & Total Number of patent Applications in nanotechnology \\
\hline 12 & LgNanoKB size (Sub- applic) & Log Number of patent applications in nanotechnology \\
\hline 13 & LgNanoKB size (Sub) & Log Number of publication in nanotechnology \\
\hline 14 & First_Patent_Nano & Dummy The first patent of the firm is nano \\
\hline 18 & DumPAT & Company which only Patents Dummy \\
\hline 19 & DumPUBPAT & Company which patent and publish Dummy \\
\hline 45 & Mean_IPC1 & Average number of classes (IPC1) \\
\hline 46 & DIV_IPC4 & Diversity Index in slightly differentiate fields (1-HHI) (IPC4) \\
\hline 49 & DIV_IPC1 & Diversity Index in related fields (1-HHI) (IPC1) \\
\hline \multicolumn{3}{|c|}{ Company size variables (from Orbis) } \\
\hline 15 & Small_firm & Small Company Dummy (i.e., not included in a larger category). \\
\hline 16 & Medium_firm & $\begin{array}{l}\text { Medium Company Dummy (operating revenue } \$ 1.4 \mathrm{~m} \text { or over, or more than } 15 \\
\text { employees) }\end{array}$ \\
\hline 17 & Large_firm & $\begin{array}{l}\text { Large Company Dummy (operating revenue } \$ 140 \mathrm{~m} \text { or over, or more than } 1000 \\
\text { employees) }\end{array}$ \\
\hline 32 & DumDTI & Firms of DTI 2008 Dummy \\
\hline \multicolumn{3}{|c|}{ Within a nanodistrict } \\
\hline 20 & DumClust & In Cluster Dummy \\
\hline \multicolumn{3}{|c|}{ Description of the DTI group (main $1400 \mathrm{R} \& \mathrm{D}$ performers worldwide) } \\
\hline 35 & GROUP_Industry & Industry of the DTI headquarter (for DTI firms) \\
\hline 36 & GROUP_NanoFirmsShare & $\%$ of subsidiaries involved in nanotechnology \\
\hline 37 & GROUP_Nanoinvolvement & $\%$ of nanopatent on the total of the patents of the group \\
\hline 38 & GROUP_EFF07 & Group's Employees (2007/2008) \\
\hline 39 & GROUP_RD07 & Group's R\&D investment(2007/2008) \\
\hline 40 & LgGROUP_EFF07 & Log Group's Employees (2007/2008) \\
\hline 41 & LgGROUP_RD07 & Log R\&D investment(2007/2008) \\
\hline
\end{tabular}


Appendix 2 : Covariance 


\begin{tabular}{|c|c|c|c|c|c|c|c|c|c|c|c|c|c|c|c|c|c|c|c|c|c|c|c|c|c|c|}
\hline $\begin{array}{l}\text { pearman } \\
\text { orrelation } \\
\text { oefficients } \\
\text { rob }>|r| \\
\text { nder H0: Rho= }\end{array}$ & 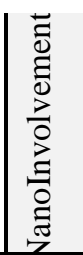 & a & 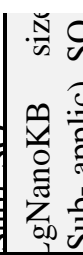 & 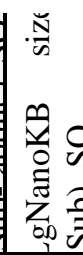 & 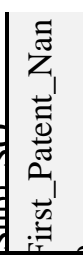 & 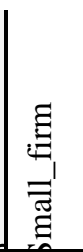 & ב⿱ & 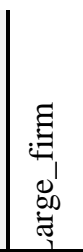 & 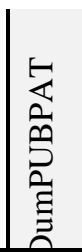 & $\begin{array}{l}\stackrel{\vec{s}}{\Xi} \\
\underline{\Xi} \\
\Xi\end{array}$ & ङ & 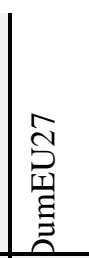 & 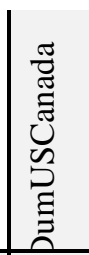 & 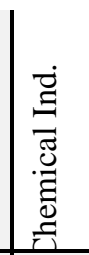 & 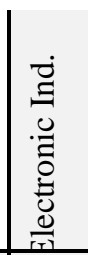 & $\begin{array}{l}\vec{Z} \\
\Xi \\
2 \\
0 \\
2 \\
0 \\
2 \\
0\end{array}$ & 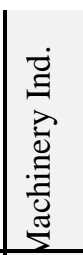 & 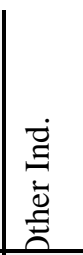 & 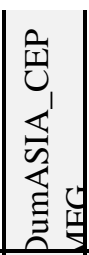 & 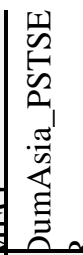 & 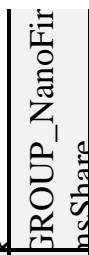 & 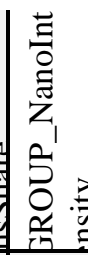 & 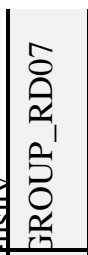 & 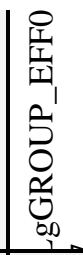 & 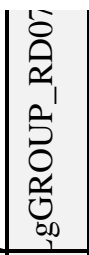 & S \\
\hline volveme & 1,00 & $\begin{array}{l}-0,66 \\
<009\end{array}$ & $\begin{array}{l}-0,06 \\
0,04\end{array}$ & $-0,04$ & $\begin{array}{l}0,47 \\
<, 0001\end{array}$ & $\begin{array}{l}0,10 \\
0,00\end{array}$ & \begin{tabular}{|l|}
0,22 \\
$<, 0001$
\end{tabular} & $\begin{array}{l}0,16 \\
<, 0001\end{array}$ & $\begin{array}{l}1,1 \\
0,00 \\
0,99\end{array}$ & $\begin{array}{l}-0,01 \\
0,76\end{array}$ & $\begin{array}{l}1 \\
-0,29 \\
<, 0001\end{array}$ & $\begin{array}{l}1,1 \\
0,01 \\
0,83\end{array}$ & $\begin{array}{l}0,24 \\
<, 0001\end{array}$ & $\begin{array}{l}0,01 \\
0,71\end{array}$ & 0,01 & 0,10 & $\begin{array}{l}-0,01 \\
0,65\end{array}$ & $\begin{array}{l}-0,07 \\
0,02\end{array}$ & \begin{tabular}{|l|}
$-0,09$ \\
0,00
\end{tabular} & $\begin{array}{l}1,1 \\
0,03 \\
0,38\end{array}$ & $\begin{array}{l}0,11 \\
0,00\end{array}$ & $\begin{array}{l}0,62 \\
<, 0001\end{array}$ & $\begin{array}{l}-0,20 \\
<, 0001\end{array}$ & $\begin{array}{l}-0,20 \\
<, 0001\end{array}$ & $\begin{array}{l}0,20 \\
<, 0001\end{array}$ & \\
\hline $\begin{array}{ll}\mathrm{gKB} & \text { size } \\
\mathrm{Sub}) \_S Q & \\
\end{array}$ & $\begin{array}{l}-0,66 \\
<, 0001\end{array}$ & 1,00 & $\begin{array}{l}0,76 \\
<, 0001\end{array}$ & 01 & $\begin{array}{l}5 \\
001\end{array}$ & 01 & 001 & 23 & $\begin{array}{l}25 \\
0001\end{array}$ & 8001 & & 01 & $\begin{array}{l}-0,09 \\
0,00\end{array}$ & 34 & 2 & 01 & 0,71 & 3 & & 5 & 0 & 01 & & & & \\
\hline $\begin{array}{lr}\mathrm{KB} & \text { size } \\
\text { plic)_SQ }\end{array}$ & $\begin{array}{l}-0,06 \\
0,04\end{array}$ & \begin{tabular}{l|l|}
6 \\
001
\end{tabular} & & & 1 & 1 & 01 & 01 & 1001 & & & & $\begin{array}{l}0,08 \\
0,01\end{array}$ & & & & & & & $\begin{array}{l}02 \\
12\end{array}$ & $\begin{array}{l}05 \\
2\end{array}$ & & & & & \\
\hline $\begin{array}{l}\text { KB size } \\
Q\end{array}$ & $\begin{array}{l}0,04 \\
0,19\end{array}$ & \begin{tabular}{|l|}
0,36 \\
$<, 0001$
\end{tabular} & & 1, & $\begin{array}{l}-0,01 \\
0,84\end{array}$ & & $\begin{array}{l}10 \\
00\end{array}$ & & 8001 & & & & $\begin{array}{l}0 \\
0\end{array}$ & & & & & & & & & & & & & \\
\hline tent_Na & $\begin{array}{l}0,47 \\
<, 0001\end{array}$ & 01 & 1 & $\begin{array}{l}-0,01 \\
0,84\end{array}$ & 00 & 0,03 & & $\begin{array}{l}0,06 \\
0,05\end{array}$ & & & & & 0 & & & & & & & & & & & & & \\
\hline$m$ & 0,00 & 001 & & & $\begin{array}{l}0,07 \\
0,03 \\
\end{array}$ & 1,00 & 0,00 & & & & 0,00 & & \begin{tabular}{|l|}
0,15 \\
$<, 0001$ \\
\end{tabular} & & 0, & & & & & & & & & & & \\
\hline$m$ & \begin{tabular}{|l|}
0,22 \\
$<, 0001$ \\
\end{tabular} & $\begin{array}{l}0,23 \\
<, 0001 \\
\end{array}$ & $\begin{array}{l}-0,12 \\
<, 0001 \\
\end{array}$ & $\begin{array}{l}-0,10 \\
0,00 \\
\end{array}$ & $\begin{array}{l}0,16 \\
<, 0001 \\
\end{array}$ & $\begin{array}{l}-0,10 \\
0,00 \\
\end{array}$ & 1,00 & $\begin{array}{l}0,13 \\
<, 0001 \\
\end{array}$ & $\begin{array}{l}-0,07 \\
0,03 \\
\end{array}$ & $\begin{array}{l}-0,07 \\
0,02 \\
\end{array}$ & $\begin{array}{l}-0,16 \\
<, 0001 \\
\end{array}$ & $\begin{array}{l}-0,05 \\
0,09 \\
\end{array}$ & $\begin{array}{l}0,17 \\
<, 0001 \\
\end{array}$ & $\begin{array}{l}-0,11 \\
0,00 \\
\end{array}$ & 0 & & & & & & & & & & $\begin{array}{l}-0,02 \\
0,50 \\
\end{array}$ & \\
\hline & $\begin{array}{l}0,16 \\
<, 0001\end{array}$ & \begin{tabular}{|l|}
$-0,23$ \\
$<, 0001$
\end{tabular} & $\begin{array}{l}-0,15 \\
<, 0001\end{array}$ & $\begin{array}{l}-0,16 \\
<, 0001\end{array}$ & $\begin{array}{l}0,06 \\
0,05\end{array}$ & $\begin{array}{l}-0,14 \\
<, 0001\end{array}$ & $\begin{array}{l}-0,13 \\
<, 0001\end{array}$ & 1,00 & $\begin{array}{l}0,16 \\
<, 0001\end{array}$ & $\begin{array}{l}-0,17 \\
<, 0001\end{array}$ & $\begin{array}{l}-0,17 \\
<, 0001\end{array}$ & $\begin{array}{l}0,08 \\
0,01\end{array}$ & 0,06 & $\begin{array}{l}0,01 \\
0,68\end{array}$ & $\begin{array}{l}-0,08 \\
0,01\end{array}$ & $\begin{array}{l}0,08 \\
0,01\end{array}$ & $\begin{array}{l}-0,01 \\
0,66\end{array}$ & & $\begin{array}{l}-0,09 \\
0,00\end{array}$ & $\begin{array}{l}-0,03 \\
0,39\end{array}$ & $\begin{array}{l}0,05 \\
0,09\end{array}$ & $0,0,11$ & $\begin{array}{l}-0,09 \\
0,00\end{array}$ & $\begin{array}{l}0,09 \\
0,00\end{array}$ & $\begin{array}{l}-0,09 \\
0,00\end{array}$ & \\
\hline & 0,00 & \begin{tabular}{|l|}
0,25 \\
$<, 0001$
\end{tabular} & $\begin{array}{l}0,31 \\
<, 0001\end{array}$ & \begin{tabular}{|l|}
0,88 \\
$<, 0001$
\end{tabular} & 0,01 & $-0,10$ & & & 1,00 & $\begin{array}{l}0,92 \\
<, 0001\end{array}$ & & & 0,02 & & $\begin{array}{l}0,07 \\
0,02\end{array}$ & & & & 0,09 & & & 36 & & & 38 & \\
\hline & $\begin{array}{l}-0,01 \\
0,76\end{array}$ & $\begin{array}{l}0,27 \\
<, 0001 \\
\end{array}$ & $\begin{array}{l}0,34 \\
<, 0001\end{array}$ & $\begin{array}{l}0,85 \\
<, 0001 \\
\end{array}$ & $\begin{array}{l}0,00 \\
0,98\end{array}$ & 0,00 & $\begin{array}{l}-0,07 \\
0,02\end{array}$ & $\begin{array}{l}-0,17 \\
<, 0001\end{array}$ & $\begin{array}{l}0,92 \\
<, 0001\end{array}$ & 1.00 & $<, 0001$ & & 0,21 & 0,00 & 0,01 & & 0,50 & & $\begin{array}{l}0,10 \\
0,00\end{array}$ & & $\begin{array}{l}0,05 \\
0,12\end{array}$ & & & $\begin{array}{l}01 \\
70\end{array}$ & $\begin{array}{l}0,05 \\
0,08\end{array}$ & 000 \\
\hline & $\begin{array}{l}-0,29 \\
<, 0001\end{array}$ & $\begin{array}{l}0,33 \\
<, 0001\end{array}$ & $\begin{array}{l}0,17 \\
<, 0001\end{array}$ & <,0001 & $\begin{array}{l}-0,09 \\
0,00\end{array}$ & 0,00 & $\begin{array}{l}-0,16 \\
<, 0001\end{array}$ & $\begin{array}{l}-0,17 \\
<, 0001\end{array}$ & $\begin{array}{l}0,17 \\
<, 0001\end{array}$ & $<, 0001$ & 1,00 & $<, 0001$ & $\begin{array}{l}-0,39 \\
<, 0001\end{array}$ & $\begin{array}{l}-0,01 \\
0,74\end{array}$ & 0,00 & & $\begin{array}{l}0,02 \\
0,51\end{array}$ & & <,0001 & 0,00 & $\begin{array}{l}-0,04 \\
0,21\end{array}$ & $<, 0001$ & 0,36 & 0,66 & $\begin{array}{l}-0,03 \\
0,36\end{array}$ & $<, 0001$ \\
\hline & 0,01 & $<, 0001$ & $\begin{array}{l}-0,18 \\
<, 0001\end{array}$ & $\begin{array}{l}-0,14 \\
<, 0001 \\
\end{array}$ & 0,39 & 0,01 & 0,09 & 0,01 & $<, 0001$ & $<, 0001$ & $<, 0001$ & 1,00 & $<, 0001$ & 0,33 & 0,00 & 0,04 & 0,10 & 0,00 & & & 0,70 & 0,65 & 0,02 & 0,00 & 0,02 & $<, 0001$ \\
\hline & $\begin{array}{l}0,24 \\
<, 0001\end{array}$ & $\begin{array}{l}-0,09 \\
0,00\end{array}$ & & & 0,10 & $<, 0001$ & $\begin{array}{l}0,17 \\
<, 0001\end{array}$ & $\begin{array}{l}0,06 \\
0,06\end{array}$ & 0,46 & 0,21 & & & & 0,15 & & & & & & 0,16 & & & & & $\begin{array}{l}-0,01 \\
0,66\end{array}$ & 0,00 \\
\hline & 0,01 & $\begin{array}{l}0,06 \\
0,04\end{array}$ & $\begin{array}{l}0,09 \\
0,00\end{array}$ & 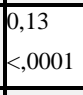 & $\begin{array}{l}-0,02 \\
0,48\end{array}$ & $\begin{array}{l}-0,10 \\
0,00\end{array}$ & $\begin{array}{l}-0,11 \\
0,00\end{array}$ & $\begin{array}{l}0,01 \\
0,68\end{array}$ & $\begin{array}{l}0,12 \\
<, 0001 \\
\end{array}$ & 0,10 & $\begin{array}{l}-0,01 \\
0,74\end{array}$ & $\begin{array}{l}-0,03 \\
0,33\end{array}$ & $\begin{array}{l}0,04 \\
0,15 \\
\end{array}$ & 1,00 & $\begin{array}{l}-0,25 \\
<, 0001\end{array}$ & $\begin{array}{l}-0,16 \\
<, 0001\end{array}$ & $\begin{array}{l}-0,15 \\
<, 0001\end{array}$ & & & $\begin{array}{l}-0,03 \\
0,29\end{array}$ & $\begin{array}{l}0,05 \\
0,13\end{array}$ & $\begin{array}{l}0,06 \\
0,05\end{array}$ & $\begin{array}{l}0,00 \\
0,89\end{array}$ & & $\begin{array}{l}0,00 \\
0,89\end{array}$ & {$\left[\begin{array}{l}0,06 \\
0,03\end{array}\right.$} \\
\hline & $\begin{array}{l}0,01 \\
0,65\end{array}$ & $\begin{array}{l}0,05 \\
0,12 \\
\end{array}$ & $\begin{array}{l}0,06 \\
0,05\end{array}$ & $\begin{array}{l}0,06 \\
0,05\end{array}$ & $\begin{array}{l}0,02 \\
0,43 \\
\end{array}$ & 0,00 & $\begin{array}{l}0,03 \\
0,31\end{array}$ & $\begin{array}{l}-0,08 \\
0,01 \\
\end{array}$ & 0,02 & 0,01 & 0,00 & 0,00 & 0,62 & $<, 0001$ & f & $<, 0001$ & $<, 0001$ & $<, 0001$ & $<, 0001$ & $\begin{array}{l}-0,03 \\
0,35\end{array}$ & $\begin{array}{l}0,00 \\
0,98 \\
\end{array}$ & $\begin{array}{l}0,00 \\
0,97 \\
\end{array}$ & $\begin{array}{l}0,01 \\
0,69 \\
\end{array}$ & 0,61 & $\begin{array}{l}0,01 \\
0,69\end{array}$ & $\begin{array}{l}0,05 \\
0,09\end{array}$ \\
\hline & $\begin{array}{l}0,10 \\
0,00\end{array}$ & \begin{tabular}{|l|}
$-0,12$ \\
$<, 0001$ \\
\end{tabular} & $\begin{array}{l}-0,05 \\
0,08 \\
\end{array}$ & $\begin{array}{l}-0,02 \\
0,49 \\
\end{array}$ & $\begin{array}{l}0,06 \\
0,06\end{array}$ & \begin{tabular}{|l|}
0,12 \\
$<, 0001$ \\
\end{tabular} & \begin{tabular}{|l|l|}
0,22 \\
$<, 0001$ \\
\end{tabular} & $\begin{array}{l}0,08 \\
0,01\end{array}$ & 0,70 & 0,96 & $\begin{array}{l}-0,14 \\
<, 0001 \\
\end{array}$ & 0,04 & 0,02 & $\begin{array}{l}-0,16 \\
<, 0001 \\
\end{array}$ & $\begin{array}{l}-0,14 \\
<, 0001 \\
\end{array}$ & 1,00 & $\begin{array}{l}-0,09 \\
0,00\end{array}$ & $<, 0001$ & $\begin{array}{l}-0,07 \\
0,01\end{array}$ & \begin{tabular}{|l|}
0,20 \\
$<, 0001$ \\
\end{tabular} & $\begin{array}{l}0,07 \\
0,02\end{array}$ & 0,07 & $\begin{array}{l}0,00 \\
0,97\end{array}$ & $\begin{array}{l}0,01 \\
0,70\end{array}$ & $\begin{array}{l}0,00 \\
0,97\end{array}$ & $<, 0001$ \\
\hline & $\begin{array}{l}-0,01 \\
0,65\end{array}$ & $\begin{array}{l}0,01 \\
0,71\end{array}$ & $\begin{array}{l}0,00 \\
0,98\end{array}$ & $\begin{array}{l}-0,01 \\
0,80\end{array}$ & $\begin{array}{l}-0,02 \\
0,48\end{array}$ & $\begin{array}{l}-0,05 \\
0,13\end{array}$ & $\begin{array}{l}0,03 \\
0,30\end{array}$ & $\begin{array}{l}-0,01 \\
0,66\end{array}$ & $\begin{array}{l}-0,01 \\
0,77\end{array}$ & $\begin{array}{l}-0,02 \\
0,50 \\
\end{array}$ & $\begin{array}{l}0,02 \\
0,51\end{array}$ & $\begin{array}{l}-0,05 \\
0,10 \\
\end{array}$ & 0,25 & $\begin{array}{l}-0,15 \\
<, 0001\end{array}$ & $\begin{array}{l}-0,14 \\
<, 0001 \\
\end{array}$ & 0,00 & 0 & $\begin{array}{l}-0,26 \\
<, 0001\end{array}$ & $\begin{array}{l}-0,07 \\
0,02\end{array}$ & $\begin{array}{l}-0,02 \\
0,56\end{array}$ & 0,01 & $\begin{array}{l}-0,05 \\
0,11\end{array}$ & $\begin{array}{l}-0,04 \\
0,23\end{array}$ & $\begin{array}{l}-0,05 \\
0,08\end{array}$ & $\begin{array}{l}-0,04 \\
0,23\end{array}$ & $\begin{array}{l}01 \\
, 64\end{array}$ \\
\hline & $\begin{array}{l}-0,07 \\
0,02\end{array}$ & $\mid \begin{array}{l}-0,02 \\
0,43\end{array}$ & $\begin{array}{l}-0,09 \\
0,00\end{array}$ & $\begin{array}{l}-0,14 \\
<, 0001\end{array}$ & $\begin{array}{l}-0,02 \\
0,49\end{array}$ & $\begin{array}{l}0,13 \\
<, 0001\end{array}$ & $\begin{array}{l}-0,07 \\
0,01\end{array}$ & $\begin{array}{l}0,01 \\
0,63\end{array}$ & $\begin{array}{l}-0,16 \\
<, 0001\end{array}$ & $\begin{array}{l}-0,14 \\
<, 0001\end{array}$ & $\begin{array}{l}0,00 \\
0,98\end{array}$ & $\begin{array}{l}0,09 \\
0,00\end{array}$ & $\begin{array}{l}-0,10 \\
0,00\end{array}$ & $\begin{array}{l}-0,47 \\
<, 0001\end{array}$ & $\begin{array}{l}-0,42 \\
<, 0001\end{array}$ & $\begin{array}{l}-0,27 \\
<, 0001\end{array}$ & $\begin{array}{l}0,20 \\
<, 0001\end{array}$ & 1,00 & $\begin{array}{l}-0,22 \\
<, 0001\end{array}$ & $\begin{array}{l}-0,05 \\
0,07\end{array}$ & $\begin{array}{l}-0,08 \\
0,01\end{array}$ & $\begin{array}{l}-0,05 \\
0,08\end{array}$ & $\begin{array}{l}0,01 \\
0,81\end{array}$ & $\begin{array}{l}0,16 \\
<, 0001\end{array}$ & $\begin{array}{l}0,01 \\
0,81\end{array}$ & $\begin{array}{l}-0,03 \\
0,31\end{array}$ \\
\hline rans & 09 & 16 & 11 & 0,09 & 0,01 & $-0,05$ & $-0,08$ & $-0,09$ & 0,09 & 10 & $\overline{44}$ & $-0,19$ & $-0,17$ & $-0,13$ & .53 & $-0,07$ & $-0,07$ & $\overline{, 22}$ & $\overline{00}$ & $-0,01$ & 0,02 & 0,06 &, 02 &, 03 &, 02 & 6 \\
\hline
\end{tabular}




\begin{tabular}{|c|c|c|c|c|c|c|c|c|c|c|c|c|c|c|c|c|c|c|c|c|c|c|c|c|c|c|}
\hline PMFG & 0,00 & $<, 0001$ & 0,00 & 0,00 & 0,66 & 0,08 & 0,01 & 0,00 & 0,00 & 0,00 & $<, 0001$ & $<, 0001$ & $<, 0001$ & $<, 0001$ & $k, 0001$ & 0,01 & 0,02 & $<, 0001$ & & 0,62 & 0,55 & 0,05 & 0,61 & 0,26 & 0,61 & $<, 0001$ \\
\hline DumAsia_ & $-0,03$ & $-0,01$ & $-0,02$ & $-0,03$ & 0,02 & 0,03 & $-0,02$ & $-0,03$ & $-0,01$ & $-0,01$ & 0,11 & $-0,05$ & $-0,04$ & $-0,03$ & $-0,03$ & 0,20 & $-0,02$ & $-0,05$ & $-0,01$ & 1,00 & 0,01 & $-0,03$ & 0,07 & 0,08 & 0,07 & $\overline{0,01}$ \\
\hline PSTSER & 0,38 & 0,85 & 0,42 & 0,28 & 0,53 & 0,28 & 0,54 & 0,39 & 0,69 & 0,82 & 0,00 & 0,12 & 0,16 & 0,29 & 0,35 & $<, 0001$ & 0,56 & 0,07 & 0,62 & & 0,64 & 0,37 & 0,03 & 0,01 & 0,03 & 0,85 \\
\hline \multirow{2}{*}{$\begin{array}{l}\text { GROUP_Nano } \\
\text { FirmsShare }\end{array}$} & 0,11 & $-0,11$ & $-0,05$ & 0,01 & 0,08 & 0,02 & 0,07 & 0,05 & 0,08 & 0,05 & $-0,04$ & 0,01 & 0,03 & 0,05 & 0,00 & 0,07 & 0,01 & $-0,08$ & 0,02 & 0,01 & 1,00 & 0,12 & $-0,08$ & $-0,07$ & $-0,08$ & $-0,11$ \\
\hline & 0,00 & 0,00 & 0,12 & 0,67 & 0,01 & 0,45 & 0,03 & 0,09 & 0,01 & 0,12 & 0,21 & 0,70 & 0,36 & 0,13 & 0,98 & 0,02 & 0,74 & 0,01 & 0,55 & 0,64 & & $<, 0001$ & 0,01 & 0,03 & 0,01 & 0,00 \\
\hline GRC & 0,62 & $-0,38$ & 0,02 & $-0,03$ & 0,20 & 0,10 & 0,10 & 0,11 & $-0,01$ & $-0,01$ & $-0,29$ & $-0,01$ & 0,24 & 0,06 & 0,00 & 0,05 & $-0,05$ & $-0,05$ & $-0,06$ & $-0,03$ & 0,12 & 1,00 & $-0,33$ & $-0,33$ & $-0,33$ & $-0,38$ \\
\hline $\begin{array}{l}\text { NanoInvolvem } \\
\text { ent }\end{array}$ & $<, 0001$ & $<, 0001$ & 0,58 & 0,33 & $<, 0001$ & 0,00 & 0,00 & 0,00 & 0,86 & 0,71 & $<, 0001$ & 0,65 & $<, 0001$ & 0,05 & 0,97 & 0,07 & 0,11 & 0,08 & 0,05 & 0,37 & $k, 0001$ & & $k, 0001$ & $<, 0001$ & $<, 0001$ & $<, 0001$ \\
\hline$\overline{\text { LgGROUP }}_{-}$ & $-0,20$ & 0,20 & 0,08 & 0,01 & $-0,10$ & $-0,04$ & $-0,04$ & $-0,09$ & $-0,04$ & $-0,01$ & 0,01 & 0,11 & $-0,11$ & $-0,16$ & $-0,02$ & 0,01 & $-0,05$ & 0,16 & 0,03 & 0,08 & $-0,07$ & $-0,33$ & 0,77 & 1,00 & 0,77 & 0,20 \\
\hline EFF07 & $<, 0001$ & $<, 0001$ & 0,01 & 0,80 & 0,00 & 0,14 & 0,20 & 0,00 & 0,19 & 0,70 & 0,66 & 0,00 & 0,00 & $<, 0001$ & 0,61 & 0,70 & 0,08 & $<, 0001$ & 0,26 & 0,01 & 0,03 & $<, 0001$ & $<, 0001$ & & $<, 0001$ & $<, 0001$ \\
\hline LgGROUP & $-0,20$ & 0,22 & 0,12 & 0,07 & $-0,10$ & $-0,02$ & $-0,02$ & $-0,09$ & 0,03 & 0,05 & $-0,03$ & 0,07 & $-0,01$ & 0,00 & 0,01 & 0,00 & $-0,04$ & 0,01 & 0,02 & 0,07 & $-0,08$ & $-0,33$ & 1,00 & 0,77 & 1,00 & 0,22 \\
\hline RD07 & $<, 0001$ & $<, 0001$ & $<, 0001$ & 0,02 & 0,00 & 0,61 & 0,50 & 0,00 & 0,38 & 0,08 & 0,36 & 0,02 & 0,66 & 0,89 & 0,69 & 0,97 & 0,23 & 0,81 & 0,61 & 0,03 & 0,01 & $<, 0001$ & $<, 0001$ & $<, 0001$ & & $<, 0001$ \\
\hline \multirow[t]{2}{*}{$\overline{\text { DIV_IPC4 }}$} & $-0,67$ & 1,00 & 0,75 & 0,35 & $-0,44$ & $-0,13$ & $-0,23$ & $-0,23$ & 0,25 & 0,27 & 0,34 & $-0,16$ & $-0,08$ & 0,06 & 0,05 & $-0,13$ & 0,01 & $-0,03$ & 0,16 & $-0,01$ & $-0,11$ & $-0,38$ & 0,22 & 0,20 & 0,22 & 1,00 \\
\hline & $<, 0001$ & $<, 0001$ & $<, 0001$ & $<, 0001$ & $<, 0001$ & $<, 0001$ & $<, 0001$ & $<, 0001$ & $<, 0001$ & $<, 0001$ & $<, 0001$ & $<, 0001$ & 0,00 & 0,03 & 0,09 & $<, 0001$ & 0,64 & 0,31 & $<, 0001$ & 0,85 & 0,00 & $<, 0001$ & $<, 0001$ & $<, 0001$ & $<, 0001$ & \\
\hline
\end{tabular}


Appendix 3. Model with all variables to explain the nano-involvement of subsidiary

\begin{tabular}{|c|c|c|c|c|}
\hline \multicolumn{5}{|c|}{ Analysis of Variance } \\
\hline Source & $\mathrm{DF}$ & $\begin{array}{l}\text { Sum of Mean } \\
\text { Squares }\end{array}$ & F Value & $\operatorname{Pr}>\mathrm{F}$ \\
\hline Model & 24 & $43.11297 \quad 1.79637$ & 129.95 & $<.0001$ \\
\hline Error & 1042 & $14.40414 \quad 0.01382$ & & \\
\hline Corrected Total & 1066 & 57.51710 & & \\
\hline
\end{tabular}

\begin{tabular}{lrr}
\hline Root MSE & 0.11757 & R-Square 0.7496 \\
\hline
\end{tabular}

\begin{tabular}{llll}
\hline Dependent Mean 0.13710 & Adj R-Sq & 0.7438
\end{tabular}

Coeff Var $\quad 85.75925$ 


\begin{tabular}{|c|c|c|c|c|c|c|}
\hline \multicolumn{7}{|l|}{ Parameter Estimates } \\
\hline Variable & Label & DF & $\begin{array}{l}\text { Parameter } \\
\text { Estimate }\end{array}$ & $\begin{array}{l}\text { Standard } \\
\text { Error }\end{array}$ & t Value & $\operatorname{Pr}>|t|$ \\
\hline Intercept & Intercept & 1 & 0.77816 & 0.05318 & 14.63 & $<.0001$ \\
\hline LgKB size (Sub)_SQ & Square Log Number of applications & 1 & -0.00411 & 0.00024669 & -16.65 & $<.0001$ \\
\hline LgNanoKB size (Sub-applic)_SQ & Square Log Number of nano applications & 1 & 0.00817 & 0.00052286 & 15.62 & $<.0001$ \\
\hline LgNanoKB size (Sub)_SQ & Square Log Number of publication & 1 & -0.00074298 & 0.00070179 & -1.06 & 0.2900 \\
\hline First_Patent_Nano & First Patent is Nano Patent Dummy & 1 & 0.13855 & 0.01271 & 10.90 & $<.0001$ \\
\hline Small_firm & Small Company Dummy & 1 & 0.01100 & 0.01373 & 0.80 & 0.4234 \\
\hline Medium_firm & Medium Company Dummy & 1 & 0.05075 & 0.01449 & 3.50 & 0.0005 \\
\hline Large_firm & Large Company Dummy & 1 & 0.01413 & 0.01091 & 1.30 & 0.1954 \\
\hline DUMPUBPAT & Patenting \& Publication Dummy & 1 & 0.01753 & 0.01993 & 0.88 & 0.3792 \\
\hline DumClust & In Cluster Dummy & 1 & -0.02326 & 0.01981 & -1.17 & 0.2406 \\
\hline DumASIA & ASIA Dummy & 1 & 0.04741 & 0.01810 & 2.62 & 0.0089 \\
\hline DumEU27 & EU27 Dummy & 1 & 0.01864 & 0.01602 & 1.16 & 0.2449 \\
\hline DumUSCanada & US \& Canada Dummy & 1 & 0.02668 & 0.01627 & 1.64 & 0.1014 \\
\hline Chemical Ind. & Chemical MFG Dummy & 1 & -0.00794 & 0.01018 & -0.78 & 0.4356 \\
\hline Electronic Ind. & Computer \& Electronic Product MFG Dummy & 1 & 0.00482 & 0.01224 & 0.39 & 0.6934 \\
\hline S\&T Serv Ind. & Professional, Scientific \& Technical Services Dummy & 1 & 0.00203 & 0.01468 & 0.14 & 0.8899 \\
\hline Machinery Ind. & Machinery MFG Dummy & 1 & 0.00402 & 0.01417 & 0.28 & 0.7765 \\
\hline DumASIA_CEPMFG & Asia Computer \& Electronic Product MFG Dummy & 1 & -0.03520 & 0.02225 & -1.58 & 0.1140 \\
\hline DumAsia_PSTSER & Asia Professional, Scientific \& Technical Services Dum & 1 & -0.05526 & 0.08534 & -0.65 & 0.5174 \\
\hline GROUP_NanoFirmsShare & Group's Nano Firms Share & 1 & 0.00009747 & 0.00004566 & 2.13 & 0.0330 \\
\hline GROUP_Nanolntensity & Group's Nano Patenting Intensity & 1 & 0.32861 & 0.03672 & 8.95 & $<.0001$ \\
\hline LgGROUP_EFF07 & Log Group's Employees (2007/2008) & 1 & 0.00213 & 0.00384 & 0.56 & 0.5787 \\
\hline LgGROUP_RD07 & Log R\&D investment(2007/2008) & 1 & 0.00337 & 0.00373 & 0.90 & 0.3675 \\
\hline DIV_IPC4 & Diversity Index (1-HHI) (IPC4) & 1 & -0.73774 & 0.03023 & -24.40 & $<.0001$ \\
\hline Mean_IPC1 & Mean Number(IPC1) & 1 & 0.02540 & 0.01567 & 1.62 & 0.1054 \\
\hline
\end{tabular}


Appendix 4 : Model with best Ajd $\mathrm{R}^{2}$ to explain the nano-involvement of subsidiary

\begin{tabular}{|c|c|c|c|c|}
\hline \multicolumn{5}{|c|}{ Analysis of Variance } \\
\hline Source & $\mathrm{DF}$ & $\begin{array}{l}\text { Sum of Mean } \\
\text { Squares Square }\end{array}$ & F Value & $\operatorname{Pr}>F$ \\
\hline Model & 11 & 43.220563 .92914 & 277.76 & $<.0001$ \\
\hline Error & 1086 & 15.362450 .01415 & & \\
\hline Corrected Total & 1097 & 58.58301 & & \\
\hline
\end{tabular}

\begin{tabular}{|c|c|c|c|c|c|c|}
\hline & & $\begin{array}{l}\text { Root MSE } \\
\text { Dependent } \\
\text { Coeff Var } \\
\end{array}$ & $\begin{aligned} & \mathbf{0 . 1 1 8 9 4} \\
& \text { Mean } 0.13628 \\
& 87.27510 \\
&\end{aligned}$ & $\begin{array}{l}\text { R-Square } \\
\text { Adj R-Sq }\end{array}$ & $\frac{\mathbf{0 . 7 3 7 8}}{0.7351}$ & \\
\hline \multicolumn{7}{|l|}{ Parameter Estimates } \\
\hline Variable & Label & DF & $\begin{array}{l}\text { Parameter } \\
\text { Estimate }\end{array}$ & $\begin{array}{l}\text { Standard } \\
\text { Error }\end{array}$ & t Value & $\operatorname{Pr}>|t|$ \\
\hline Intercept & Intercept & 1 & 0.79160 & 0.04056 & 19.52 & $<.0001$ \\
\hline LgKB size (Sub)_sQ & Square Log Number of applications & 1 & -0.00408 & 0.00023945 & -17.05 & $<.0001$ \\
\hline LgNanoKB size (Sub- applic)_SQ & Square Log Number of nano applications & 1 & 0.00793 & 0.00049826 & 15.91 & $<.0001$ \\
\hline LgNanoKB size (Sub)_SQ & Square Log Number of publication & 1 & -0.00081123 & 0.00062721 & -1.29 & 0.1961 \\
\hline First_Patent_Nano & First Patent is Nano Patent Dummy & 1 & 0.13905 & 0.01258 & 11.06 & $<.0001$ \\
\hline Medium_firm & Medium Company Dummy & 1 & 0.04939 & 0.01316 & 3.75 & 0.0002 \\
\hline DumASIA & ASIA Dummy & 1 & 0.01182 & 0.00930 & 1.27 & 0.2040 \\
\hline GROUP_NanoFirmsShare & Group's Nano Firms Share & 1 & 0.00009083 & 0.00004534 & 2.00 & 0.0454 \\
\hline GROUP_NanoIntensity & Group's Nano Patenting Intensity & 1 & 0.33450 & 0.03647 & 9.17 & $<.0001$ \\
\hline LgGROUP_RD07 & Log R\&D investment(2007/2008) & 1 & 0.00490 & 0.00252 & 1.95 & 0.0520 \\
\hline DIV_IPC4 & Diversity Index (1-HHI) (IPC4) & 1 & -0.72125 & 0.02994 & -24.09 & $<.0001$ \\
\hline Mean_IPC1 & Mean Number(IPC1) & 1 & 0.03128 & 0.01490 & 2.10 & 0.0359 \\
\hline
\end{tabular}

